\title{
Towards resolving the phosphorus chaos created by food systems
}

\author{
Paul J. A. Withers (1), Kirsty G. Forber, Christopher Lyon, \\ Shane Rothwell, Donnacha G. Doody, Helen P. Jarvie, \\ Julia Martin-Ortega, Brent Jacobs, Dana Cordell, Myles Patton, \\ Miller A. Camargo-Valero, Rachel Cassidy
}

Received: 5 February 2019/Revised: 11 July 2019/Accepted: 31 August 2019/Published online: 21 September 2019

\begin{abstract}
The chaotic distribution and dispersal of phosphorus (P) used in food systems (defined here as disorderly disruptions to the $\mathrm{P}$ cycle) is harming our environment beyond acceptable limits. An analysis of $\mathrm{P}$ stores and flows across Europe in 2005 showed that high fertiliser $\mathrm{P}$ inputs relative to productive outputs was driving low system $\mathrm{P}$ efficiency (38\% overall). Regional $\mathrm{P}$ imbalance ( $\mathrm{P}$ surplus) and system $\mathrm{P}$ losses were highly correlated to total system $\mathrm{P}$ inputs and animal densities, causing unnecessary $\mathrm{P}$ accumulation in soils and rivers. Reducing regional $\mathrm{P}$ surpluses to zero increased system $\mathrm{P}$ efficiency $(+16 \%)$ and decreased total P losses by $35 \%$, but required a reduction in system $\mathrm{P}$ inputs of ca. $40 \%$, largely as fertiliser. We discuss transdisciplinary and transformative solutions that tackle the $\mathrm{P}$ chaos by collective stakeholder actions across the entire food value chain. Lowering system $\mathrm{P}$ demand and better regional governance of $\mathrm{P}$ resources appear necessary for more efficient and sustainable food systems.
\end{abstract}

Keywords Efficiency - Eutrophication · Food system · Phosphorus $\cdot$ Stakeholders $\cdot$ Sustainability

\section{INTRODUCTION}

Enrichment of the hydrosphere with phosphorus (P) used in global food production is compromising water quality and biodiversity and the provision of linked ecosystem services (MacDonald et al. 2016; Campbell et al. 2017). Mitigating the negative ecosystem impacts and high societal costs of

Electronic supplementary material The online version of this article (https://doi.org/10.1007/s13280-019-01255-1) contains supplementary material, which is available to authorized users. this eutrophication requires reductions in $\mathrm{P}$ loading to inland and coastal waterbodies (Schindler et al. 2016), but achieving these reductions in the face of continuing population growth, increasing food demand and future climate change is however problematic (Ockenden et al. 2017; Springmann et al. 2018). Whilst some rivers and lakes in developed regions have seen welcome declines in their $\mathrm{P}$ status as a result of reductions in sewage effluent discharges (e.g. European Environment Agency 2015), rates of annual $\mathrm{P}$ storage in catchments remain high because riverine $\mathrm{P}$ export is considerably less than the net anthropogenic $\mathrm{P}$ inputs entering catchments (Powers et al. 2016).

This continued and highly variable accumulation of $P$ in catchments occurs over multiple timescales and represents a long-term 'legacy' source of $\mathrm{P}$ losses to waterbodies which is difficult to mitigate (Jarvie et al. 2013; Abbott et al. 2018). Losses of $P$ in land runoff occur from multiple point and diffuse sources across urban and rural landscapes, in a spectrum of particulate and soluble $\mathrm{P}$ forms (Withers and Bowes 2018). Anthropogenic P inputs have consequently become widely and chaotically dispersed across both terrestrial and aquatic environments. In this context, chaos can be defined as the disorderly disruption of natural $\mathrm{P}$ cycling that increases the biosphere's sensitivity to small changes in environmental conditions. The chaotic dispersal of $\mathrm{P}$ in landscapes and waterscapes, in turn, reflects the chaotic governance of $\mathrm{P}$ in terms of its distribution, usage, loss and accumulation within society, the majority of which occurs within the food system (e.g. van Dijk et al. 2016). Geographical segregation of crop and livestock production systems, increasing urbanisation and global trade in food commodities have totally disrupted local production and $\mathrm{P}$ cycles in unforeseen ways driven by market forces (e.g. Jarvie et al. 2015; Nesme et al. 2018). This disorderly anthropogenic enrichment of our 
environment threatens further transition of socio-ecological systems into chaotic states that are very difficult to predict; for example in sudden ecosystem shifts to less desired states (Folke et al. 2004), or in increased vulnerability to a future scarcity of finite phosphate rock reserves (Cordell and Neset 2014).

Attempts to improve P-use efficiency and sustainability within food systems and limit $\mathrm{P}$ losses to water have hitherto typically been reductionist in character. They have focused on improved wastewater treatment to remove $\mathrm{P}$ in effluent discharge (Schindler et al. 2016), and altering farmland and landscape management to avoid overuse of $\mathrm{P}$ inputs on farms and reduce the mobilisation and delivery of $P$ in runoff from agricultural land (Kleinman et al. 2015). A focus on field and farm-scale $\mathrm{P}$ management is understandable because modern farming practices have increased land vulnerability to $\mathrm{P}$ loss in runoff and erosion (Withers and Bowes 2018), and that is the scale at which $\mathrm{P}$ is currently managed through farmer choice and decisions. However, sole reliance on agronomic solutions to $\mathrm{P}$ source management ignores the $\mathrm{P}$ inefficiencies, wastage and losses that occur at other stages in the food supply chain; for example, during the mining of phosphate rock, in food processing and arising from our consumption of food (Cordell and White 2014; Jurgilevich et al. 2016). These wider food chain inefficiencies are a consequence of societal functioning involving a wider range of stakeholders, and are therefore largely outside the control of the producer.

In this paper, we examine the distribution and dispersal of $\mathrm{P}$ used in Europe's food systems and consider some causal drivers of poor environmental performance. We find that system $\mathrm{P}$ inefficiencies and losses are related to the P-input pressure imposed by the organisation of the food system, and argue for a more transdisciplinary, transformative and system-wide approach to $\mathrm{P}$ governance and management that addresses the regional $\mathrm{P}$ imbalance that is the root cause of P unsustainability (Abson et al. 2016; Gordon et al. 2017). We consider the need for a societal response to this complex and dynamic socio-environmental issue based on the transformational potential of all stakeholders in the food chain, and discuss potential leverage mechanisms for transformative change towards improved resource conservation, environmental performance and long-term sustainability.

\section{METHODS}

Efficiencies of $\mathrm{P}$ use, surplus soil $\mathrm{P}$ accumulation and $\mathrm{P}$ losses from the food system were compared for the EU 27 countries based on the national P flows dataset for 2005 compiled using substance flow analysis (SFA) by van Dijk et al. (2016). This seminal SFA provides national data on annual $\mathrm{P}$ inputs, $\mathrm{P}$ outputs and internal $\mathrm{P}$ cycling by total amount $(\mathrm{Gg})$, and on an areal $\left(\mathrm{kg} \mathrm{P} \mathrm{ha}^{-1}\right)$ and a per capita basis $\left(\mathrm{kg} \mathrm{P} \mathrm{ca}^{-1}\right)$, Fig. S1. System $\mathrm{P}$ efficiency assessed productive $\mathrm{P}$ output as a function of $\mathrm{P}$ inputs and was defined as human consumption of $\mathrm{P}+\mathrm{P}$ exports divided by the $\mathrm{P}$ imports into the food system (fertiliser, feed and food). Whole system $\mathrm{P}$ efficiency was further sub-divided into sector efficiencies (calculated as consumed or exported $\mathrm{P}$ divided by imported and recycled $\mathrm{P}$ ) for crop production, animal production and food processing. System surplus $\mathrm{P}$ was defined as the annual amount of unused $\mathrm{P}$ that accumulated in the soil each year as detailed in van Dijk et al. (2016). The P surplus represents the imbalance or difference between total $\mathrm{P}$ inputs (i.e. imports) and total $\mathrm{P}$ outputs (i.e. P exports and P losses), Fig. S1. Total losses of P from the food system included wastewater discharges from households and industry, waste disposal via incineration and landfill and diffuse $\mathrm{P}$ losses in land runoff, all based on measured national data for each sector (households, food processing, livestock and crop production, Fig. S1) as reviewed by van Dijk et al. (2016). Specific sub-losses of P to water which included direct municipal wastewater discharges (termed effluent losses), runoff losses from livestock hardstandings and runoff, leaching and soil erosion from agricultural soils (termed soil losses) were also calculated. Flows of P into and out of the non-food system in each country were excluded from the calculations. In addition to land area and population, national data on arable land (including temporary grass), permanent pasture, total livestock units, and wealth (taken as Gross Domestic Product) for 2005 were obtained from the Eurostat pocketbook database (European Commission 2007) to help identify some causal relationships and efficiency indicators.

Efficiency, surplus and P loss metrics by area and per capita were compared to national indicators by single and multiple linear regression analysis using SPSS v25. Malta was excluded from areal comparisons due to their exceptionally small area relative to their P flows. Non-linear fitting was preferred where this gave a significant $(P<0.05)$ improvement over a linear function in the variance accounted for. To aid interpretation, the EU 27 countries were allocated to Western, Eastern, Northern and Southern regions of Europe according to their climate zones (Table S1).

The dispersal and accumulation of food system $\mathrm{P}$ inputs into terrestrial and aquatic landscapes was assessed by the variability in bioavailable $\mathrm{P}$ in EU soils and rivers. Dispersal of $\mathrm{P}$ in soils was quantified by the variation in the mean concentrations of Olsen-extractable $\mathrm{P}$ in cropland and grassland sampled across Europe in 2009 (and part 2012) as part of the LUCAS survey (Tóth et al. 2013). Data 
were not available for Bulgaria, Cyprus, Luxembourg, Malta and Romania. Olsen-P is a metric of crop-available inorganic $\mathrm{P}$ reserves in soil arising from the cumulative $\mathrm{P}$ surpluses generated over time in farming systems (Tóth et al. 2013). This metric is not always the best predictor of crop $P$ availability, depending on soil type, but nevertheless provides a common measure of soil $\mathrm{P}$ fertility status across Europe. A mean agronomic optimal Olsen-P for Europe of $20 \mathrm{mg} \mathrm{kg}^{-1}$ (Nawara et al. 2017) was used to illustrate how much Olsen-P has deviated from the level required for optimal growth of grass and arable crops. Full descriptive statistics of all national soil survey data used in this analysis are given in Table S2.

Dispersal of $\mathrm{P}$ in EU rivers was quantified by the mean concentrations of soluble reactive $\mathrm{P}$ (SRP) relative to nitrate- $\mathrm{N}\left(\mathrm{NO}_{3} \mathrm{~N}\right)$ measured as part of the Waterbase survey v 14 (European Environment Agency 2018b). The values represent the mean of all national river SRP and $\mathrm{NO}_{3} \mathrm{~N}$ data submitted to the European Commission for the period 2003-2007 (or closest to this). This five-year period was chosen as it spans the year the national food system flows were calculated by van Dijk et al. (2016). No data were available for Malta. As these data are produced using different methodologies, additional data are also given on mean SRP and $\mathrm{NO}_{3}-\mathrm{N}$ concentrations in different river and land runoff typologies representative of lowland England using standardised catchment monitoring protocols (Withers et al. 2009; Neal et al. 2012). A mean eutrophication control target of $0.06 \mathrm{mg}$ SRP $\mathrm{L}^{-1}$ was used here to illustrate the extent of impairment of freshwaters with respect to readily bioavailable $\mathrm{P}$ (Withers and Bowes 2018). Full descriptive statistics of all national river and runoff survey data used in this analysis are given in Tables S3-S5.

\section{RESULTS}

Total annual imports of $\mathrm{P}$ into the food system (here also termed P-input pressure) ranged up to $144 \mathrm{~kg} \mathrm{P} \mathrm{ha}^{-1}$ and $15 \mathrm{~kg} \mathrm{P} \mathrm{ca}^{-1}$ across the EU 27. Fertiliser was often the largest P import (64\% for all Europe), but imported animal feed was the largest $\mathrm{P}$ import in the Czech Republic, Denmark and Slovenia, whilst food P imports dominated in Belgium, Cyprus, Estonia, Latvia, Luxembourg, Malta and The Netherlands. Multiple regression analysis showed that total system $\mathrm{P}$ imports were primarily dependent on animal densities $(P<0.001)$, which were closely linked to population densities (Fig. 1A, B). At the national level, fertiliser $\mathrm{P}$ imports were also related to animal densities $(P<0.001$, $r^{2}=0.43$ ) rather than to agricultural land area.

Whole system P efficiency varied from 22 to $139 \%$ within individual countries, and was $38 \%$ for all Europe.
Values above $100 \%$ (i.e. $\mathrm{P}$ outputs $>\mathrm{P}$ inputs) occurred more in North-Eastern Europe where large reductions in cropland area and fertiliser use have occurred since the fall of communism (Fig. 1C; Kuemmerle et al. 2017). However, $\mathrm{P}$ imports exceeded productive $\mathrm{P}$ outputs in the majority of EU countries (Table 1). Imported fertiliser P was the best predictor of whole system $\mathrm{P}$ efficiency (Table 2 and Fig. 1C), with lowest $\mathrm{P}$ efficiencies occurring in Spain (22\%), Ireland (24\%), Portugal (26\%), Greece $(26 \%)$ and Poland (29\%) because agricultural P output per hectare was low despite high fertiliser $\mathrm{P}$ inputs.

Sector $\mathrm{P}$ efficiencies in crop production, livestock production and food processing ranged from 14 to $129 \%$ (69 $\%$ overall), $14-52 \%$ (24\% overall) and $62-88 \%$ (78\% overall), respectively. The much lower $\mathrm{P}$ efficiencies associated with livestock production were because the large amounts of $\mathrm{P}$ recycled in manure were not classed as consumed or exported $\mathrm{P}$ outputs. The near tenfold variation in crop production $\mathrm{P}$ efficiency, which declined as areal fertiliser $\mathrm{P}$ imports increased $\left(P<0.001, r^{2}=0.61\right)$, had a much larger influence on overall system $P$ efficiency than either livestock $\mathrm{P}$ efficiency or food processing efficiency (Fig. 1D). Particularly low crop production efficiencies were recorded in Southern Europe because of larger areal $\mathrm{P}$ fertiliser inputs needed on the high proportion of calcareous soils in that region, and lower crop outputs due to the more limited water availability (Torrent et al. 2007). Countries with high animal production efficiencies had greater imports of animal feed and food which generated greater production output, and this was reflected in a significant positive relationship with GDP. Food processing efficiency was decreased as system $\mathrm{P}$ imports on a per capita basis increased (Table S6).

Excluding the small island of Malta, which had a disproportionally small land area (Table 1), the amounts of surplus $\mathrm{P}$ accumulating in the soil annually across Europe varied from -3 to $29 \mathrm{~kg} \mathrm{P} \mathrm{ha}^{-1}$ year $^{-1}$ or -1.0 to $6.94 \mathrm{~kg}$ $\mathrm{P} \mathrm{ca}^{-1}$ year ${ }^{-1}$ (representing up to $70 \%$ of the $\mathrm{P}$ imported into the food system). These surpluses are in excellent agreement to the gross soil $\mathrm{P}$ balance for 2005 ( -7 to $28 \mathrm{~kg} \mathrm{P} \mathrm{ha}{ }^{-1}$ ) estimated independently by the European Commission (Eurostat: https://ec.europa.eu/eurostat/web/ products-datasets/-/t2020_rn310). Areal P surpluses were significantly positively correlated with system $\mathrm{P}$ inputs, especially fertiliser inputs (Fig. 2A), and declined as crop production efficiency and total system $\mathrm{P}$ efficiency increased (e.g. Fig. 2B). Animal density was also a significant $(P<0.001)$ cause of variation in system $P$ surplus (Table 2). Largest $P$ surpluses therefore occurred in Western Europe where $\mathrm{P}$ inputs and livestock densities were highest, especially in Belgium and the Netherlands (Fig. 2B), and this was again reflected in a significant positive relationship with GDP (Table 2). The results from 

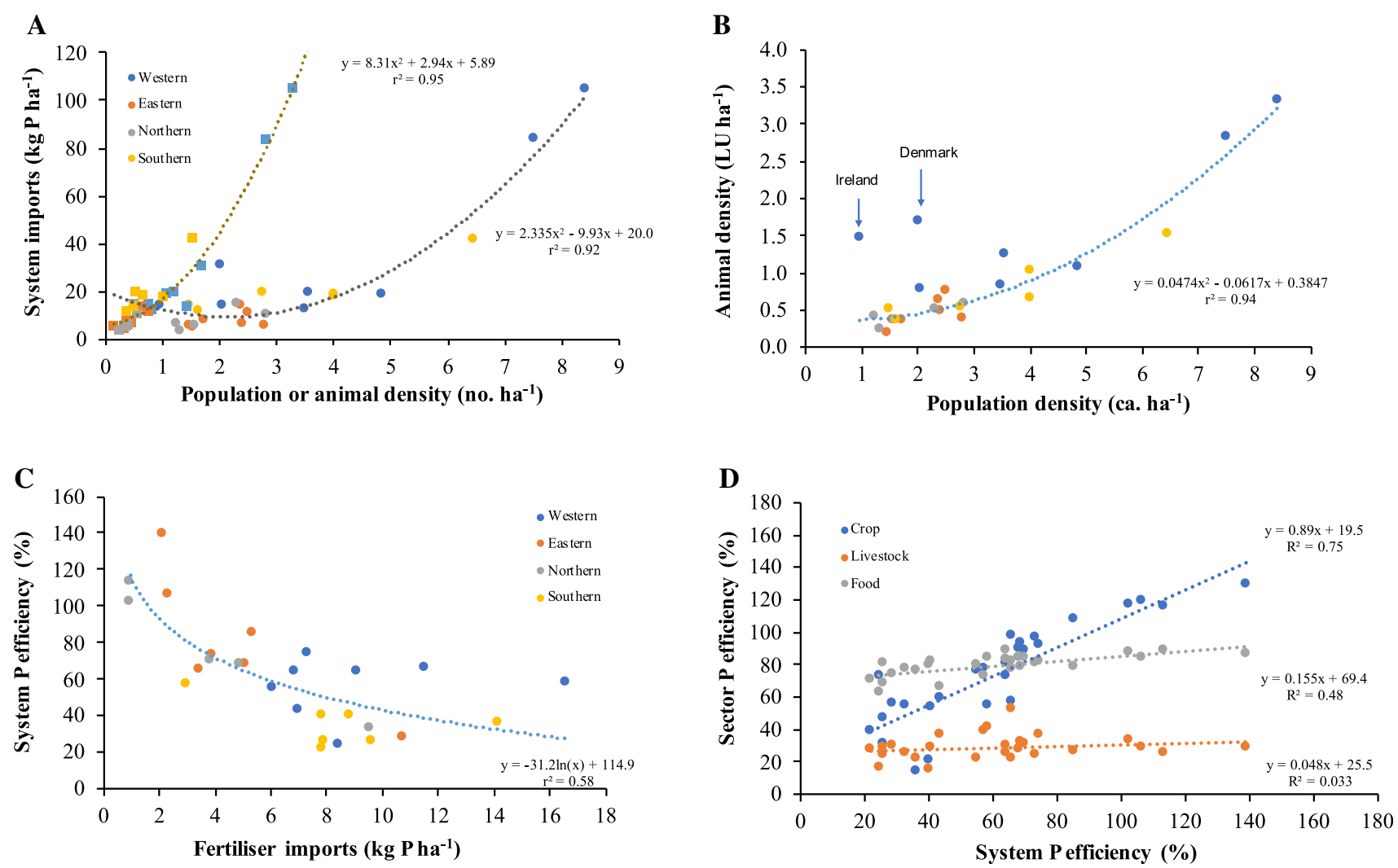

Fig. 1 Imports of P into the food system defining the P-input pressure which is a function of population density and animal density (a). Denmark and Ireland have higher animal densities relative to the human population (b) because of the dominance of the livestock sector in their agricultural systems. System P efficiency is largely controlled by fertiliser imports (c), because of the dominant influence of cropland efficiency on overall system efficiency (d). For definitions of system and sector efficiencies, see the text. Data are derived from the P flows in 2005 across the EU 27 countries compiled by van Dijk et al. (2016) and EU demographical data (European Commission 2007) for 2005

the LUCAS soil survey showed that countries with higher $\mathrm{P}$ surpluses (and GDP) also tended to have greater Olsen-P concentrations in the soil $(P<0.001$, Fig. 2 C). Olsen-P concentrations ranged from 24 to $84 \mathrm{mg} \mathrm{kg}^{-1}$ (mean $43.3 \mathrm{mg} \mathrm{kg}^{-1}$, S.E. 3.03) in cropland soils and from 23 to $68 \mathrm{mg} \mathrm{kg}^{-1}$ (mean $36.3 \mathrm{mg} \mathrm{kg}^{-1}$, S.E. 2.44) in grassland soils. The link between soil Olsen-P and livestock density was particularly strong (Fig. 2D) due to the contribution from recycled manure $P$ inputs.

Total $\mathrm{P}$ losses from the food system ranged from 2 to $23 \mathrm{~kg} \mathrm{P} \mathrm{ha}^{-1}$ and from 1.34 to $4.7 \mathrm{~kg} \mathrm{P} \mathrm{ca}^{-1}$, and increased markedly at a rate of $20 \%$ of system P imports (Fig. 3A). Even with zero $\mathrm{P}$ imports, $\mathrm{P}$ losses averaged $2.60 \mathrm{~kg} \mathrm{ha}^{-1}$. However, in contrast to system $\mathrm{P}$ surpluses, total P losses from the food system were governed more by feed and food imports $\left(P<0.001, r^{2}=0.87\right)$ than by fertiliser imports, and were highly positively correlated equally to both population density and animal density (Fig. 3B). Together these two factors explained $93 \%$ of the variation in system total $\mathrm{P}$ losses, which were consequently also strongly related to GDP. There was no relationship between Olsen-P levels and soil losses of $\mathrm{P}$ to water
(Table 2). Total P losses to water were weakly related to both animal density and population density $\left(P<0.01, r^{2}=\right.$ 0.3 ), but were not significantly related to the mean concentrations of SRP in rivers across the EU27 which ranged from 0.14 to $0.31 \mathrm{mg} \mathrm{L}^{-1}$ (Fig. 3C). River SRP levels were significantly higher where effluent losses were high $\left(P=0.003, r^{2}=0.31\right)$. However, mean river SRP concentrations across Europe were generally in excess of the eutrophication control target, especially for individual rivers in regions receiving both high effluent $\mathrm{P}$ losses and land runoff from intensive farming (Fig. 3D; Table S3).

\section{DISCUSSION}

\section{Drivers of $P$ inefficiency, surplus and loss}

Substance flow analysis is a widely accepted and valuable model to compare stores and flows of $\mathrm{P}$ in complex systems after accounting for data uncertainty and their socioeconomic contexts (Chowdhury et al. 2014; Metson et al. 2015). The dataset produced by van Dijk et al. (2016) 
Table 1 Food system's general characteristics, P flows and efficiency metrics across the EU in 2005. Data are derived from the P flows in 2005 across the EU 27 countries compiled by van Dijk et al. (2016) and EU data on crop area and animal numbers (European Commission 2007) for 2005. For definitions of system inputs, productive outputs, system losses, efficiency and surplus metrics, see text and Fig. S1. $M$ million, $L U$ Livestock units, $G g$ Gigograms

\begin{tabular}{|c|c|c|c|c|c|c|c|c|c|c|c|c|}
\hline \multirow[t]{3}{*}{ Country } & \multicolumn{4}{|c|}{ Characteristics } & \multicolumn{3}{|c|}{ P flows } & \multicolumn{4}{|l|}{ Metrics } & \multirow{3}{*}{$\begin{array}{l}\text { Surplus } \\
\left(\mathrm{kg} \mathrm{P} \mathrm{ha}^{-1}\right)\end{array}$} \\
\hline & \multirow{2}{*}{$\begin{array}{l}\text { Land } \\
\text { (M ha) }\end{array}$} & \multirow{2}{*}{$\begin{array}{l}\text { Animals } \\
\text { (M LU) }\end{array}$} & \multirow{2}{*}{$\begin{array}{l}\text { People } \\
\text { (M) }\end{array}$} & \multirow{2}{*}{$\begin{array}{l}\text { GDP } \\
\left(€ \times 10^{12}\right)\end{array}$} & \multirow{2}{*}{$\begin{array}{l}\text { Inputs } \\
(\mathrm{Gg})\end{array}$} & \multirow{2}{*}{$\begin{array}{l}\text { Outputs } \\
(\mathrm{Gg})\end{array}$} & \multirow{2}{*}{$\begin{array}{l}\text { Losses } \\
(\mathrm{Gg})\end{array}$} & \multicolumn{4}{|c|}{ Efficiency ( \%) } & \\
\hline & & & & & & & & System & Crop & Animal & Food & \\
\hline Belgium & 1.39 & 3.88 & 10.41 & 0.335 & 115.4 & 67.5 & 28.9 & 59 & 54 & 41 & 84 & 23.25 \\
\hline Bulgaria & 5.26 & 0.87 & 7.74 & 0.029 & 26.5 & 19.4 & 16.6 & 73 & 96 & 24 & 81 & -0.07 \\
\hline Czech Republic & 4.26 & 2.06 & 10.25 & 0.127 & 25.7 & 27.3 & 21.4 & 106 & 118 & 28 & 84 & -2.11 \\
\hline Denmark & 2.69 & 4.52 & 5.42 & 0.227 & 81.3 & 35.4 & 26.9 & 44 & 58 & 36 & 66 & 10.10 \\
\hline Germany & 16.99 & 18.12 & 82.59 & 2.423 & 315.5 & 235.2 & 158.9 & 75 & 91 & 36 & 81 & 1.77 \\
\hline Estonia & 0.85 & 0.31 & 1.35 & 0.015 & 4.3 & 4.4 & 2.9 & 102 & 116 & 32 & 87 & -1.10 \\
\hline Ireland & 4.29 & 6.20 & 4.16 & 0.191 & 57.2 & 14.0 & 19.6 & 24 & 73 & 16 & 62 & 6.73 \\
\hline Greece & 6.86 & 2.46 & 11.18 & 0.228 & 77.8 & 20.1 & 36.2 & 26 & 46 & 24 & 68 & 5.92 \\
\hline Spain & 28.95 & 14.40 & 43.38 & 1.051 & 387.3 & 85.1 & 115.2 & 22 & 38 & 28 & 71 & 9.00 \\
\hline France & 29.56 & 22.66 & 60.98 & 1.892 & 406.1 & 260.6 & 131.6 & 64 & 80 & 25 & 82 & 3.77 \\
\hline Italy & 14.61 & 9.54 & 58.76 & 1.536 & 263.2 & 106.4 & 125.9 & 40 & 53 & 28 & 81 & 7.49 \\
\hline Cyprus & 0.16 & 0.24 & 1.03 & 0.016 & 6.7 & 2.4 & 2.3 & 36 & 14 & 22 & 76 & 28.91 \\
\hline Latvia & 1.75 & 0.41 & 2.30 & 0.021 & 5.3 & 6.0 & 4.2 & 113 & 115 & 25 & 88 & -0.91 \\
\hline Lithuania & 2.75 & 1.12 & 3.41 & 0.028 & 16.4 & 11.5 & 7.1 & 70 & 88 & 30 & 84 & 0.78 \\
\hline Luxembourg & 0.13 & 0.16 & 0.46 & 0.036 & 2.5 & 1.6 & 0.7 & 64 & 73 & 30 & 88 & 6.14 \\
\hline Hungary & 5.84 & 2.10 & 10.10 & 0.101 & 46.5 & 39.6 & 26.2 & 85 & 107 & 26 & 79 & -0.99 \\
\hline Malta & 0.01 & 0.05 & 0.42 & 0.005 & 1.4 & 0.6 & 0.8 & 40 & 20 & 14 & 79 & 58.08 \\
\hline Netherlands & 1.94 & 6.39 & 16.29 & 0.567 & 202.4 & 133.2 & 47.4 & 66 & 56 & 52 & 82 & 21.94 \\
\hline Austria & 3.25 & 2.44 & 8.22 & 0.271 & 35.7 & 24.5 & 22.6 & 69 & 92 & 32 & 78 & -0.14 \\
\hline Poland & 16.06 & 10.15 & 38.12 & 0.309 & 219.6 & 62.8 & 88.6 & 29 & 55 & 29 & 73 & 7.42 \\
\hline Portugal & 3.80 & 2.02 & 10.54 & 0.163 & 73.8 & 19.1 & 25.9 & 26 & 31 & 28 & 80 & 13.25 \\
\hline Romania & 14.10 & 4.93 & 21.80 & 0.124 & 61.5 & 40.3 & 60.4 & 66 & 97 & 22 & 76 & -0.31 \\
\hline Slovenia & 0.50 & 0.51 & 2.00 & 0.035 & 8.6 & 4.9 & 6.4 & 57 & 77 & 38 & 73 & -2.82 \\
\hline Slovakia & 1.94 & 0.74 & 5.41 & 0.055 & 9.9 & 13.8 & 8.3 & 139 & 129 & 28 & 86 & -0.40 \\
\hline Finland & 2.28 & 1.16 & 5.25 & 0.180 & 32.8 & 10.7 & 13.1 & 33 & 54 & 25 & 77 & 7.43 \\
\hline Sweden & 3.18 & 1.80 & 9.06 & 0.331 & 32.1 & 21.9 & 18.6 & 68 & 89 & 27 & 83 & 0.49 \\
\hline United Kingdom & 17.29 & 14.27 & 60.44 & 2.049 & 207.3 & 114.3 & 122.7 & 55 & 75 & 22 & 80 & 4.21 \\
\hline
\end{tabular}

provided an opportunity to examine the $\mathrm{P}$ dynamics in food systems across Europe, and how they might relate to the dispersion and accumulation of $\mathrm{P}$ in their catchments, as assessed here by the LUCAS soil survey and the Waterbase river survey. Our analysis showed that high P-input pressure, either defined by area or per capita, reduced cropland and overall system $\mathrm{P}$ efficiency and increased system $\mathrm{P}$ surpluses and losses (Figs. 1, 2 and 3, Tables 2 and S6). Fertiliser $\mathrm{P}$ input was clearly the main driver of changes in system $\mathrm{P}$ efficiency through its effect on cropland efficiency. A reduction in average fertiliser use of $1 \mathrm{~kg} \mathrm{ha}^{-1}$ across Europe gave a $6 \%$ increase in cropland P efficiency and a $5 \%$ increase in system P efficiency in 2005. Multiple regression analysis indicated that $95 \%$ of the variation in system P imports was explained solely by differences in animal density to meet the population demand for meat and dairy products. In addition to animal feed imports, high fertiliser $P$ imports are needed to meet this demand because, across Europe as a whole, $63 \%$ of crop production $\mathrm{P}$ output is fed to livestock. In many EU countries, fertiliser $\mathrm{P}$ inputs are therefore still too high relative to the productive $\mathrm{P}$ output, and this oversupply is also reflected at a global scale (Helin and Weikard 2019).

The largest surpluses and losses of $\mathrm{P}$ were in Western Europe with both high population density and intensive animal agriculture and this was reflected in strong links to national wealth (GDP). Surpluses were most strongly linked to fertiliser inputs as the dominant $\mathrm{P}$ import, and above an apparent minimum average fertiliser $\mathrm{P}$ demand across Europe of $4 \mathrm{~kg} \mathrm{P} \mathrm{ha}{ }^{-1}$, the regional $\mathrm{P}$ surplus increased by $1.9 \mathrm{~kg} \mathrm{ha}^{-1}$ for every additional $\mathrm{kg}$ of fertiliser used (Fig. 2A). A strong link between fertiliser P 
Table 2 Correlation coefficients $\left(r^{2}\right)$ from linear regression analysis of factors potentially influencing $\mathrm{P}$ efficiency, $\mathrm{P}$ surplus and $\mathrm{P}$ losses in the food systems across the EU27 countries and their relationships to national data on mean soil Olsen-P and mean river-soluble reactive P (SRP) concentrations. System data are expressed on an areal basis. The results of regression analysis expressed on a per capita basis are given in Table S6. Asterisks give statistical significance: $* P<0.05$; $* * P<0.01$; $* * * P<0.001$. $L U$ livestock unit, $U A A$ utilizable agricultural area, $G D P$ gross domestic product. $N S$ not significant $(P>0.05)$

\begin{tabular}{|c|c|c|c|c|c|c|c|c|c|c|c|c|}
\hline \multirow{3}{*}{$\begin{array}{l}\text { Dependent } \\
\text { variable }\end{array}$} & \multicolumn{12}{|c|}{ Independent variable } \\
\hline & \multirow{2}{*}{$\begin{array}{l}\text { Population } \\
\text { density } \\
\left(\text { ca. } \mathrm{ha}^{-1}\right)\end{array}$} & \multirow{2}{*}{ 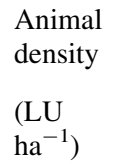 } & \multirow{2}{*}{$\begin{array}{l}\text { UAA } \\
\text { (ha) }\end{array}$} & \multirow{2}{*}{$\begin{array}{l}\text { GDP } \\
(\mathrm{M} € \\
\left.\mathrm{ha}^{-1}\right)\end{array}$} & \multicolumn{4}{|l|}{$\mathrm{P}$ imports } & \multirow{2}{*}{$\begin{array}{l}\text { P surplus } \\
\left(\mathrm{kg} \mathrm{ha}^{-1}\right)\end{array}$} & \multicolumn{3}{|l|}{$\mathrm{P}$ losses } \\
\hline & & & & & $\begin{array}{l}\text { System } \\
\left(\mathrm{kg} \mathrm{ha}^{-1}\right)\end{array}$ & Fertiliser & Feed & Food & & $\begin{array}{l}\text { System } \\
\left(\mathrm{kg} \mathrm{ha}^{-1}\right)\end{array}$ & Effluent & Soil \\
\hline \multicolumn{13}{|l|}{$\mathrm{P}$ efficiency (\%) } \\
\hline System & NS & NS & NS & NS & NS & $-0.42 * * *$ & NS & NS & $-0.25^{*}$ & NS & NS & NS \\
\hline Crop production & $-0.15^{*}$ & $-0.16^{*}$ & NS & NS & $-0.21^{*}$ & $-0.66 * * *$ & NS & NS & $-0.63 * * *$ & $-0.16^{*}$ & $-0.16^{*}$ & NS \\
\hline Animal production & $0.43 * * *$ & $0.45 * * *$ & NS & $0.38 * *$ & $0.52 * * *$ & NS & $0.62 * * *$ & $0.55 * * *$ & NS & $0.60 * * *$ & NS & NS \\
\hline Food processing & NS & NS & NS & NS & NS & NS & NS & NS & NS & NS & NS & NS \\
\hline Surplus $\left(\mathrm{kg} \mathrm{P} \mathrm{ha}^{-1}\right)$ & $0.51 * * *$ & $0.54 * * *$ & NS & $0.30 * *$ & $0.63 * * *$ & $0.79 * * *$ & $0.46 * * *$ & $0.54 * * *$ & - & $0.47 * * *$ & $0.36 * *$ & NS \\
\hline \multicolumn{13}{|l|}{ Losses $\left(\mathrm{kg} \mathrm{P} \mathrm{ha}^{-1}\right)$} \\
\hline System & $0.83 * * *$ & $0.85 * * *$ & NS & $0.57 * * *$ & $0.89 * * *$ & $0.37 * *$ & $0.86 * * *$ & $0.86 * * *$ & $0.47 * * *$ & - & $0.25 *$ & NS \\
\hline Effluent & $0.28 * *$ & $0.31 * *$ & NS & $0.23 *$ & $0.34 * *$ & $0.24 *$ & $0.19 *$ & $0.40 * * *$ & $0.18 *$ & $0.34 * *$ & - & NS \\
\hline Soil & NS & NS & NS & NS & NS & NS & NS & NS & NS & NS & NS & - \\
\hline \multicolumn{13}{|l|}{ Olsen-P (mg kg $\left.{ }^{-1}\right)$} \\
\hline Cropland & $0.74 * * *$ & $0.85 * * *$ & NS & $0.79 * * *$ & $0.79 * * *$ & $0.36 * *$ & $0.76 * * *$ & $0.75 * * *$ & $0.48 * *$ & $0.76 * * *$ & NS & $0.22 *$ \\
\hline Grassland & $0.49 * * *$ & $0.66 * * *$ & NS & $0.63 * * *$ & $0.63 * * *$ & $0.59 * * *$ & $0.47 * * *$ & $0.60 * * *$ & $0.64 * * *$ & $0.49 * * *$ & NS & NS \\
\hline River SRP $\left(\mathrm{mg} \mathrm{L}^{-1}\right)$ & NS & NS & NS & NS & NS & NS & NS & NS & NS & NS & $0.31 * *$ & NS \\
\hline
\end{tabular}

inputs and $\mathrm{P}$ surplus at national scale has also been shown in temporal analyses of national $\mathrm{P}$ budgets (Withers et al. 2014, 2018). Those countries with the largest $P$ imports, and animal densities that determine areal manure $\mathrm{P}$ loadings to agricultural land, also had the highest concentrations of Olsen-P in both cropland and grassland soils because of the surpluses they generated (Figs. 2, 3). This link to soil $\mathrm{P}$ status was significant even though Olsen-P is an indicator of cumulative surplus $\mathrm{P}$ inputs over many years rather than those generated in only 1 year.

Total losses of $\mathrm{P}$ from the food system were high (ca. 20 $\%$ of inputs) and reflect the multiple hotspots of $\mathrm{P}$ cycling within the food chain that increase $\mathrm{P}$ loss vulnerability: wastewater treatment, slaughter and food waste, manure handling and land management. The lack of a significant relationship between $\mathrm{P}$ losses to water and mean river SRP concentrations across Europe is perhaps not surprising given the complex seasonal transfers and cycling of $\mathrm{P}$ across the land-water interface. Highly variable spatial and temporal patterns of $\mathrm{P}$ delivery and retention of different particulate and dissolved forms of $\mathrm{P}$ during storm events and complex lag patterns of SRP release from legacy $\mathrm{P}$ stores in the landscape make it very difficult to identify single causal factors (Powers et al. 2016; Dupas et al. 2018; Withers and Bowes 2018). The Waterbase survey did not have sufficient data on total $\mathrm{P}$ concentrations to allow cross-country comparisons to food system $\mathrm{P}$ flows. The significant but weak relationship between effluent losses (areal or per capita basis, Tables 2 and S6) and mean river SRP levels is however consistent with previous work that has demonstrated the beneficial impact of lowering effluent losses on river SRP concentrations across Europe (e.g. Foy 2007; European Environment Agency 2015). The wide dispersal of the anthropogenic $\mathrm{P}$ imported and circulating in the food system is exemplified by the highly variable, elevated nutrient signals found in both soils and waters, and this will likely become exaggerated by climate change (Forber et al. 2018).

\section{An agronomic issue or a wider food chain issue?}

Overuse of $\mathrm{P}$ inputs relative to food $\mathrm{P}$ demand is not only wasteful of critical phosphate rock resources but also generates surpluses and losses of unused $\mathrm{P}$ that are damaging our environment. Europe is almost entirely dependent on imports of $\mathrm{P}$ to secure its food supply, yet its overall P-use efficiency in 2005 was low (38\%) and the average $\mathrm{P}$ surplus and $\mathrm{P}$ loss from the EU food system was ca. 5 and $6 \mathrm{~kg} \mathrm{P} \mathrm{ha}^{-1}$, respectively. Food system $\mathrm{P}$ inefficiencies occur across multiple scales ranging from agronomic inefficiencies at field and farm scale to wider societal inefficiencies associated with the regional 

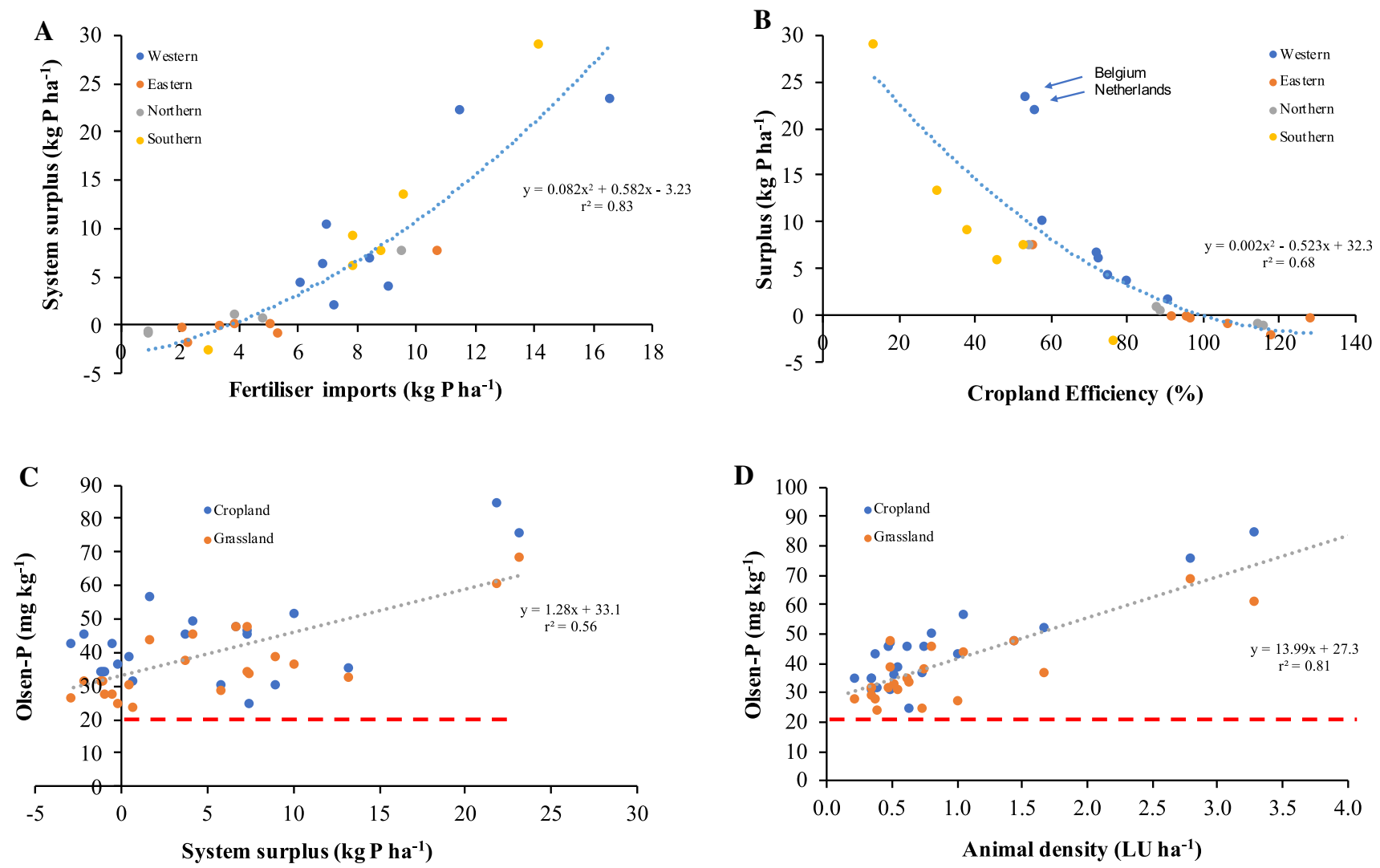

Fig. 2 Fertiliser imports exerting a large influence on system surplus P across the EU 27 (a), which becomes zero only when cropland P efficiency across all Europe is $100 \%$ (b). Belgium and the Netherlands have much higher P surpluses relative to their cropland efficiency because they have high animal densities. Countries with a high system P surplus accumulate more available P (measured as Olsen-P) in cropland and grassland soils, but this accumulation is at levels that are in excess of agronomic optimal requirements (red dotted line) (c). The large influence of animal density on system surplus is also reflected in their influence on soil Olsen-P concentrations (d). The Olsen-P data are from the EU LUCAS soil survey and represent mean values for soils in the EU 27 countries, excluding Malta (Tóth et al. 2013)

organisation of food systems, and the complex long food supply chains that have emerged as a consequence of consumer demand and global trade (Box 1). Improving the efficiency and sustainability of $\mathrm{P}$ use and reducing eutrophication impacts relies on overcoming both agronomic and wider food supply chain $\mathrm{P}$ inefficiencies to minimise $\mathrm{P}$ surpluses and losses. However, only agronomic $\mathrm{P}$ inefficiency is currently addressed to any degree in $\mathrm{P}$ source management strategies, and there is a fundamental governance disconnect between the management of $\mathrm{P}$ on individual farms and the management of $\mathrm{P}$ at regional or national scale (Leinweber et al. 2018).

In recent decades, a combination of voluntary and regulatory guidelines, measures and decision support tools have been introduced to encourage best management practices to improve agronomic $\mathrm{P}$ efficiency, and reduce land runoff and soil erosion risk (e.g. Kleinman et al. 2015). This places the burden of responsible $P$ management on the farmer and landowner, and is often undermined by farmers' innate aversion to risking practices that might lower yields, which means that they have a propensity to apply excess $\mathrm{P}$ to offset uncertainty (Buckley and Carney 2013). A further underlying issue confounding sole reliance on the success of agronomic solutions is that their site-specific nature makes them variably cost-effective and liable to failure during extreme events (e.g. Ockenden et al. 2017).

In contrast to agronomic inefficiency, the wider supply chain P inefficiencies associated with food production, processing, retailing and consumption are not wholly addressed, although strategic frameworks to foster sustainable $\mathrm{P}$ use across multiple scales and stakeholder groups have been proposed (Cordell and Neset 2014; Metson et al. 2015; Withers et al. 2015). From a complex systems perspective, a whole system cannot be sustainable if only a sub-system is optimised. Food systems are generating $\mathrm{P}$ surpluses at catchment, regional and national scales because the home-grown and imported nutrients consumed and excreted by animals and humans are not uniformly balanced with cropland demand at a regional or national scale (Box 1). This is not a new phenomenon as regional nutrient imbalances have been in existence for at 

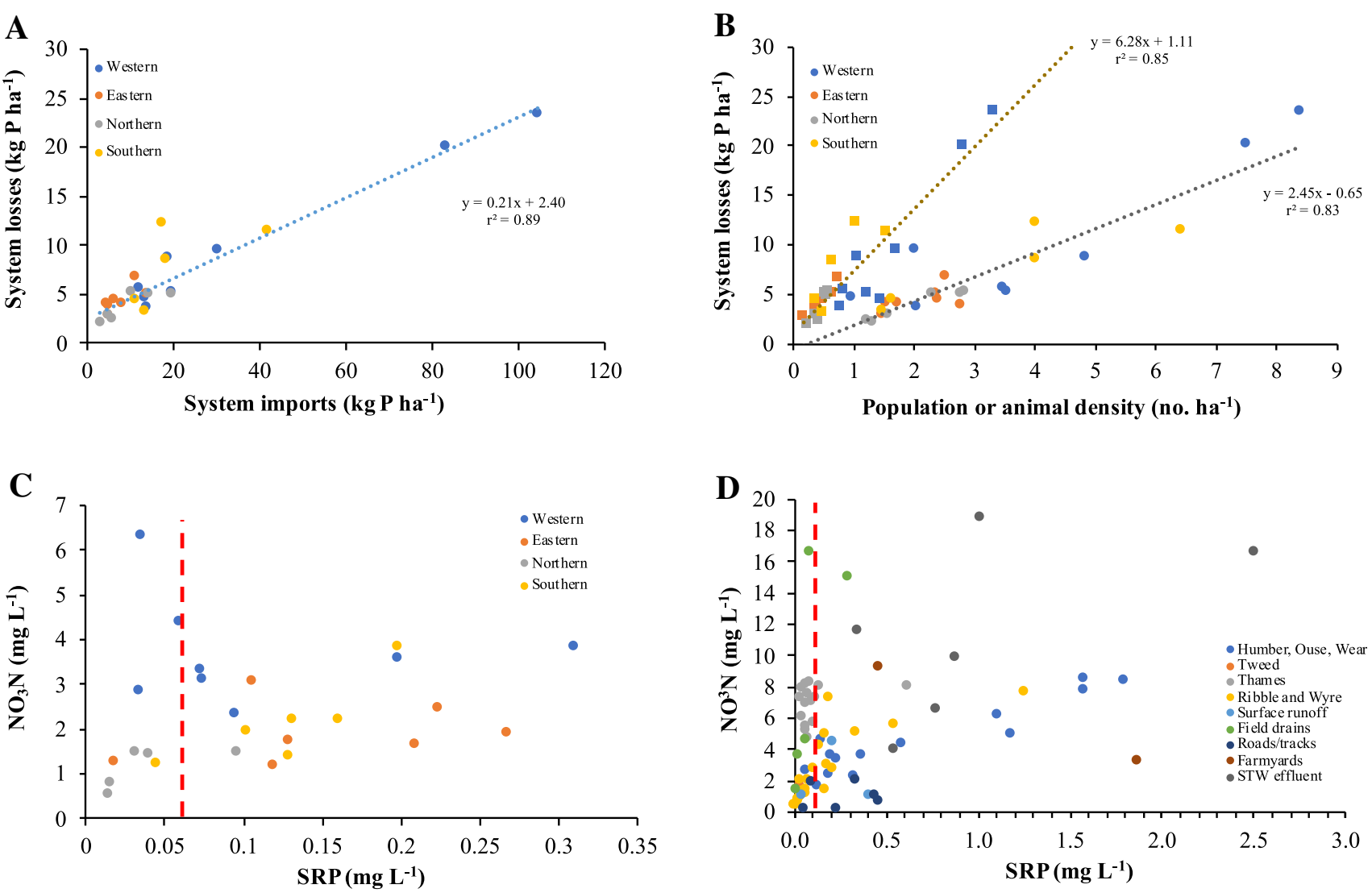

Fig. 3 System $\mathrm{P}$ imports driving system total $\mathrm{P}$ losses (to water and to landfill) across the EU27 (a), with variation in $\mathrm{P}$ losses very largely explained by differences in animal and population densities that govern the P-input pressure (b). Mean soluble reactive P (SRP) and nitrate-N $\left(\mathrm{NO}_{3} \mathrm{~N}\right)$ concentrations in rivers vary widely across Europe (c), and are largely in excess of $\mathrm{P}$ targets for eutrophication control (red dotted line). More extreme nutrient pollution of land runoff and individual rivers is typical of highly populated countries with intensive agriculture such as the UK (D). EU river data are from the Waterbase v14 nutrient survey (European Environment Agency 2018a, b) and data from the UK are from intensive catchment monitoring programmes (Withers et al. 2009; Neal et al. 2012)

least two centuries (e.g. DeGraef 2017), but the scale of the problem has become more acute with urbanisation and the globalisation of feed and food supply (MacDonald et al. 2011; Gordon et al. 2017). Current policies try to address $\mathrm{P}$ imbalance only at an individual farm scale. Our analysis suggests that achieving a zero $\mathrm{P}$ surplus at regional scale would lead to a more $\mathrm{P}$ efficient food system, and reduce total $\mathrm{P}$ losses by ca. $35 \%$. The relationships between system $\mathrm{P}$ inputs and $\mathrm{P}$ surplus indicate an overall reduction in system P imports of ca. $40 \%$ from the 2005 level, largely as fertiliser, is necessary to deliver zero $\mathrm{P}$ surplus across Europe.

Recent initiatives towards more sustainable agricultural development via a circular $\mathrm{P}$ economy will help to close the $\mathrm{P}$ cycle and reduce dependence on $\mathrm{P}$ imports (Jurgilevich et al. 2016; Withers et al. 2018). However, the potential for $\mathrm{P}$ recovery and recycling is currently being left to the open market, and maybe confounded by variable economic, agronomic performance and/or regulatory restrictions. Consequently, regional $\mathrm{P}$ imbalances persist. Similarly, there is no apparent policy awareness of the need to reduce $\mathrm{P}$ demand pressure across the whole food system to improve overall $\mathrm{P}$ efficiency and reduce surplus $\mathrm{P}$ accumulation and subsequent losses (Fig. 2A). Europe has reduced its consumption of imported $\mathrm{P}$ fertilisers by ca. 15 $\%$ since 2005 , and this will have increased system efficiency by $5 \%$, reduce system $\mathrm{P}$ surplus by $35 \%$ and reduce total $\mathrm{P}$ loss by $5 \%$ (Figs. $1 \mathrm{C}, 2 \mathrm{~A}$, and $3 \mathrm{~A}$ ). This reduction in $\mathrm{P}$ use was in response to a market shock (the price of phosphate rock rose over $800 \%$ in 2008), rather than a concerted drive towards greater P-use efficiency, and lower $\mathrm{P}$ inputs cannot be sustained without also reducing $\mathrm{P}$ demand if long-term food productivity is not to be compromised (Withers et al. 2018). Lowering $P$ demand might be best achieved by reducing livestock densities since this appears as the main driver of total system $\mathrm{P}$ imports (Fig. 1A). Our analysis suggests a $20 \%$ reduction in livestock density across Europe would stimulate lower system $\mathrm{P}$ imports by ca. $3 \mathrm{~kg} \mathrm{ha}^{-1}$, which in turn would help to reduce total system $\mathrm{P}$ losses by at least $0.6 \mathrm{~kg} \mathrm{ha}^{-1}$, (Figs. 1A, 3A). 
Box 1 Inefficiencies of phosphorus use in food systems operate at multiple scales

\section{Agronomic $\mathbf{P}$ inefficiencies}

Inherent inefficiencies in nutrient use arise at field and farm scale because of (a) the natural immobilisation of $\mathrm{P}$ by biotic (i.e. microbial) and abiotic (i.e. physicochemical) processes in soils that compete with plants for the nutrients available,

(b) uncertainties in the prediction of economically optimal amounts of $P$ required by different crops and animals in different seasons, and (c) leakage of $\mathrm{P}$ from soils along different hydrological pathways into surface and groundwaters. Agronomic inefficiencies are influenced by farmer decisions on land use, land management and nutrient inputs and the landscape characteristics that determine $\mathrm{P}$ mobility. Large $\mathrm{P}$ inefficiencies will arise on P-fixing soils, when $\mathrm{P}$ inputs deviate from crop and animal $\mathrm{P}$ demand or output, and due to a mismatching of production practices with land capability and runoff risk fuelled by food production subsidies. Rural landscapes have been abused by modern farming practices that have degraded the ecosystem attributes that determine the future resilience of food production systems to global stressors (e.g. climate, market and resource shocks).

\section{Wider food chain $\mathbf{P}$ inefficiencies}

Inherent inefficiencies in nutrient utilisation also occur at other stages in the food supply chain because the recirculation of nutrients between crops, animals and humans has become disrupted over space and time in unintended ways by (a) the specialisation and industrialisation of agriculture that has geographically segregated crop and animal production systems, (b) by the extensive urbanisation and international trade that has preferentially concentrated nutrients into urban areas with little of those nutrients returned to where the food is produced, (c) general economic growth and affluence that has favoured meat-rich diets and (d) wastage related to pre-farm gate P supply chains including the $\mathrm{P}$ losses that occur during mining, fertiliser processing, storage and transport (depending on the country of production and length of the supply chain). Such broad infrastructure changes have resulted in considerable imbalance in nutrient flows between and across regions, and shifts in the types of food being consumed. These society-driven $\mathrm{P}$ inefficiencies have occurred due to the highly variable economic and social development of agriculture and related markets in different regions, and have been evolving for some considerable time. These wider P inefficiencies are more important in determining eutrophication risk than agronomic inefficiencies, because they are largely responsible for the chaotic accumulation of $\mathrm{P}$ within the landscape.

Collective actions across all sectors of the food chain are therefore needed to reduce and manage both P supply and demand pressures in order to resolve the regional $\mathrm{P}$ imbalances causing environmental damage (Cordell and White 2014; Springmann et al. 2018). Such collective action requires transdisciplinary approaches to flexible decision-making, embracing a diversity of 'knowledge systems' and values, an analysis of leverage interfaces within and between sub-systems of the food chain, and of interactions between stakeholders, and an understanding of their adaptive and transformative capacities (Reed 2008; Jacobs et al. 2017; Ruben et al. 2019).

\section{Developing P-sustainable systems}

Following the conceptual framework of Abson et al. (2016), we can consider two basic transdisciplinary approaches to manage $\mathrm{P}$ more sustainably across the whole food system. One approach is to better manage the parameters and feedbacks of the existing food system, whilst another approach is to reorientate the food system through more transformative adaptations in system design and intent (Fig. 4). System parameters and feedbacks include the P stores and flows in the food system, operating internal synergies towards $\mathrm{P}$ recycling, and social response to policy measures such as the introduction of agri-environment schemes (Abson et al. 2016). System adaptations to manage parameters and feedbacks might include: reducing the unnecessary use of imported $\mathrm{P}$, for example, by omitting $\mathrm{P}$ fertiliser where soil Olsen-P exceeds the agronomic optimal value (Fig. 2C); maximising opportunities to recycle existing bioresources as fertiliser substitutes, or the introduction of $\mathrm{P}$ efficiency standards to drive more sustainable P use (Fig. 4). Appropriate geographical scales for $\mathrm{P}$ governance of parameters and feedbacks are catchments and regions, where: (a) the multifunctionality of landscapes can be managed to minimise chronic $\mathrm{P}$ losses and optimise the balance of ecosystem service provision, (b) P stores and flows can be quantified to identify hotspots of societal P inefficiency and (c) business opportunities to recover and recycle $\mathrm{P}$ can be identified to overcome arablelivestock and rural-urban P imbalances (Doody et al. 2016; MacDonald et al. 2016; Powers et al. 2019). Improving P efficiency and achieving zero $P$ surplus at the regional scale requires assessment of minimum regional $\mathrm{P}$ demand based on food production needs (e.g. Helin and Weikard 2019), taking full account of legacy $\mathrm{P}$ stores in the soil, and of regional accessibility to secondary $\mathrm{P}$ resources that can substitute for $\mathrm{P}$ fertiliser and feed imports.

According to Abson et al. (2016), management interventions relating to the parameters and feedbacks in a system may have too shallow leverage to lead to sufficient beneficial change: for example, they do not alter the organisation and total $\mathrm{P}$ demand of the food system, and therefore the P-input pressure that governs overall environmental vulnerability remains (Figs. 2A, 3A). The continuing poor state of ecosystems despite considerable policy efforts to improve them suggest more transformative change is required (e.g. Díaz et al. 2019). For example, pollution is still a major cause of the failure of over $60 \%$ of surface waters in Europe to achieve good ecological status (European Environment Agency 2018a). Transformative change requires a radical reassessment of system design and intent to lower P demand, which stakeholders are best placed to influence and enact the necessary leverage and how best to achieve the transformation. For example, 


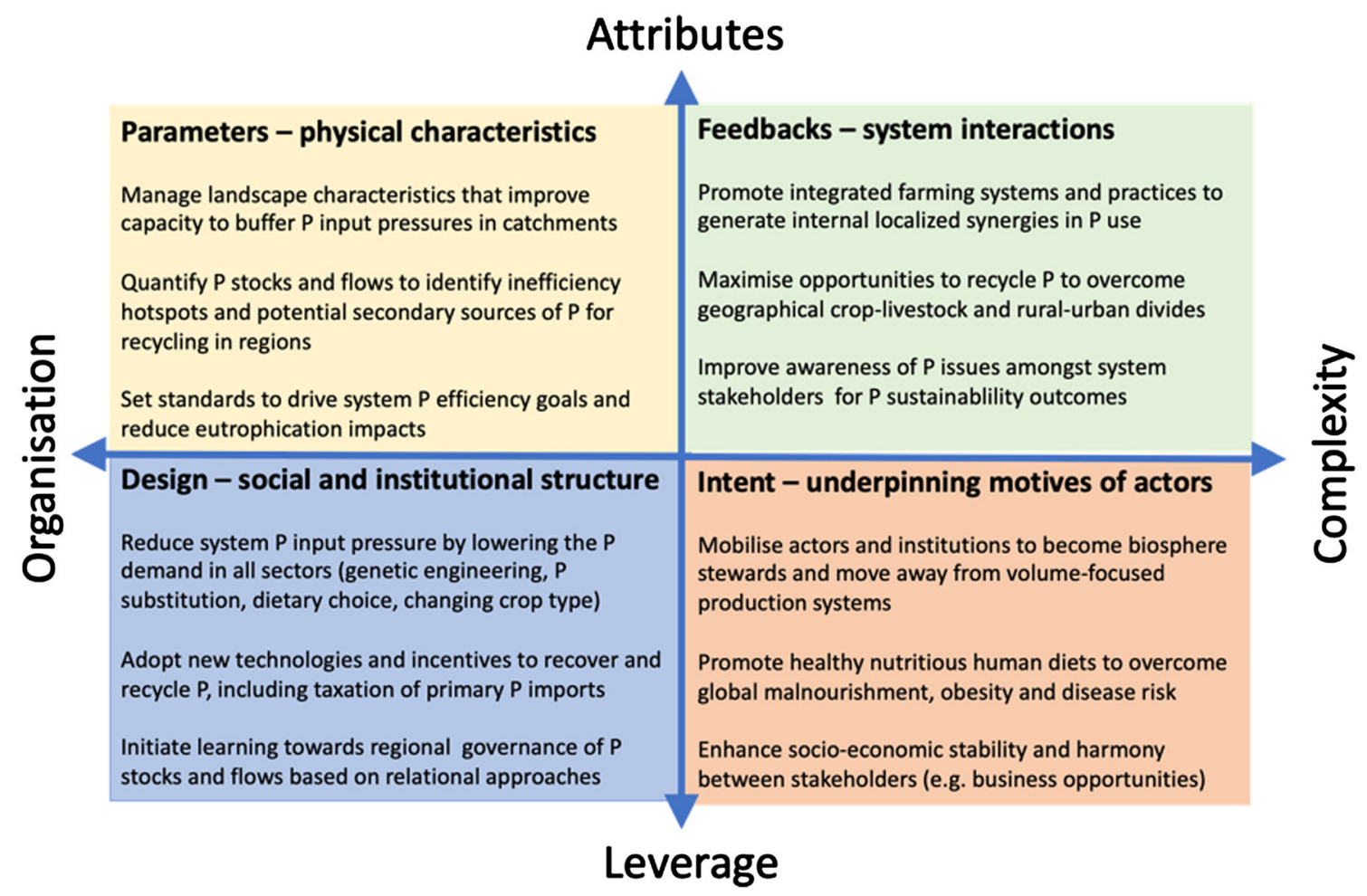

Fig. 4 Towards an understanding of the social, economic and environmental dimensions of food systems (system attributes, organisation, complexity and leverage points) based on the management and governance of their parameters, feedbacks, design and intent. The framework provides selected examples of transdisciplinary management interventions to improve P-use efficiency and reduce eutrophication risk and is based on the conceptual thinking of Abson et al. (2016) and Gordon et al. (2017)

Termeer et al. (2017) suggests that system transformation is best achieved through deep continuous change rather than wide-scale unplanned system disruption. Changes in system design might include growing the type of crops and foods that are best aligned with healthy diets, including lowering meat intake, new technologies to allow alternatives to the $\mathrm{P}$ additives used during food processing, or facilitating regional governance through mutual learning based on evidence gathering and experience of what works and what does not (Fig. 4). This includes ensuring system actors recognise their 'connectedness' to other system actors and components (McNamee and Gergen 1999).

Reorientation of system intent requires a re-examination of stakeholder motives values, power and influence, and the potential to move away from the current resource hungry economic model that values food volume more than food quality, or its sustainable production, at the expense of the environment (Jurgilevich et al. 2016; Gordon et al. 2017). Changes in intent might be enacted by reconnecting people with nature, and encouraging High Nature Value (HNV) farmers who operate on lower inputs to provide a wider range of ecosystem services benefits, such as biodiversity, in addition to their core farming activities (Lomba et al. 2014). Large stakeholders who have influenced the organisation of the food system, such as supermarkets with their own brands and supply chains (Burch and Lawrence 2005), have the potential to lever consumer preferences and production patterns in support of healthier diets and environmental integrity. For example, reducing regional $\mathrm{P}$ imbalance by sourcing locally produced food using secondary P inputs (Cordell and Neset 2014).

Research is needed to characterise the social capital and transition pathways towards such transformative change in different regions and environmental settings, taking account of synergies and trade-offs with other cycles (e.g. C, N and Water) (e.g. Metson et al. 2015; Jacobs et al. 2017). Transition pathways to address regional P imbalance must therefore disentangle the role of all stakeholders (not just farmers and landowners) on the basis of their transformational capacity and empower them to take responsibility in the collective governance of $\mathrm{P}$ beyond the farm gate. It could even be argued that truly sustainable food systems should also consider the environmental provenance of food and feed P imports beyond regional geographical boundaries (Lathuillière et al. 2014). Avoiding the traps of reductionist, agronomic-centric solutions to $\mathrm{P}$ inefficiency and pollution risk therefore means creating fair and transformative polycentric governing strategies based on a deep understanding of $\mathrm{P}$ dynamics at global to regional scales on the one hand, and stakeholder roles, 
interests, and capacities on the other. In addition to topdown policy makers, key stakeholders to enlist in transition strategy formation include farmers, local and national environmental managers, water companies, agri-businesses, charities, and other organisations with diverse but important system roles (Morrison et al. 2019).

\section{CONCLUSION}

Phosphorus is one of the biogeochemical flows from our food systems that is causing widespread environmental damage and concerns over future food security due to $\mathrm{P}$ scarcity. Inefficiencies in $\mathrm{P}$ use across time and space, surplus $\mathrm{P}$ accumulation in rural and urban environments and current production and waste disposal practices are all contributing to accelerated P losses and eutrophication of waterbodies and reduced resilience of the food system to environmental, market or resource shocks. A comparison of stores and flows of $\mathrm{P}$ across Europe have shown that $\mathrm{P}$-input pressures linked to population pressure and demand for meat and dairy products are driving highly variable $\mathrm{P}$ inefficiencies across multiple scales, surplus $\mathrm{P}$ accumulation in catchments and large losses to water and landfill. In particular, fertiliser $\mathrm{P}$ inputs are still too high in relation to productive $\mathrm{P}$ output and appear as the dominant driver of system $\mathrm{P}$ surpluses across Europe. These $\mathrm{P}$ inefficiencies and imbalances occurring across the whole food system are not currently being adequately managed because improving P-use efficiency and reducing system P losses is seen as an agronomic issue rather than a wider food chain issue. Resolving the disorderly disruptions to the $\mathrm{P}$ cycle ( $\mathrm{P}$ chaos) created by our food systems and improving their environmental performance therefore requires a shift in research agendas to focus on the whole food system and its $\mathrm{P}$ demand, and not just on landscape $\mathrm{P}$ delivery to adjacent waterbodies, or placing the burden of responsibility solely on producers. The environmental performance of food systems can only be improved by tackling the wider food chain inefficiencies that reflect societal functioning, but this requires a societal response and stakeholder interaction in addition to the current agronomic solutions. A reorientation of design and intent of the wider food system, and better management of system parameters and feedbacks alongside transdisciplinary polycentric governance of $\mathrm{P}$, is needed to lower $\mathrm{P}$ demand and deliver more $\mathrm{P}$ efficient and P-sustainable food production from local to global scales. The interdependencies of scale covering both biophysical and socioeconomic aspects of system $\mathrm{P}$ use need to be considered in more detail for this reorientation to occur.
Acknowledgements This paper was produced as part of the RePhoKUs project (The role of phosphorus in the sustainability and resilience of the UK food system) funded by BBSRC, ESRC, NERC, and the Scottish Government under the UK Global Food Security research programme (Grant No. BB/R005842/1). Funding was provided by Biotechnology and Biological Sciences Research Council (Grant No. BB/R005842/1).

Open Access This article is distributed under the terms of the Creative Commons Attribution 4.0 International License (http:// creativecommons.org/licenses/by/4.0/), which permits unrestricted use, distribution, and reproduction in any medium, provided you give appropriate credit to the original author(s) and the source, provide a link to the Creative Commons license, and indicate if changes were made.

\section{REFERENCES}

Abbott, B.W., F. Moatar, O. Gauthier, O. Fovet, V. Antoine, and O. Ragueneau. 2018. Trends and seasonality of river nutrients in agricultural catchments: 18 years of weekly citizen science in France. Science of the Total Environment 624: 845-858.

Abson, D.J., J. Fischer, J. Leventon, J. Newig, T. Schomerus, U. Vilsmaier, H. von Wehrden, P. Abernethy, et al. 2016. Leverage points for sustainability transformation. Ambio 46: 30-39.

Buckley, C., and P. Carney. 2013. The potential to reduce the risk of diffuse pollution from agriculture while improving economic performance at farm level. Environmental Science \& Policy 25: $118-126$.

Burch, D., and G. Lawrence. 2005. Supermarket own brands, supply chains and the transformation of the agri-food system. International Journal of Sociology of Agriculture and Food 13: 1-18.

Campbell, B.M., D.J. Beare, E.M. Bennett, J.M. Hall-Spencer, J.S.I. Ingram, F. Jaramillo, R. Ortiz, N. Ramankutty, et al. 2017. Agriculture production as a major driver of the Earth system exceeding planetary boundaries. Ecology and Society 22: 8. https://doi.org/10.5751/ES-09595-220408.

Chowdhury, R.B., G.A. Moore, A.J. Weatherley, and M. Arora. 2014. A review of recent substance flow analyses of phosphorus to identify priority management areas at different geographical scales. Resources, Conservation and Recycling 83: 213-228.

Cordell, D., and S. White. 2014. Life's bottleneck: Sustaining the world's phosphorus for a food secure future. Annual Review of Environment and Resources 39: 161-188.

Cordell, D., and T.-S.S. Neset. 2014. Phosphorus vulnerability: A qualitative framework for assessing the vulnerability of national and regional food systems to the multidimensional stressors of phosphorus scarcity. Global Environmental Change 24: 108-122.

Díaz, S., J. Settele, E. Brondízio, H.T. Ngo, M. Guèze, J. Agard, A. Arneth, and P. Balvanera et al. 2019. IPBES Global Summary Assessment for Policymakers. Intergovernmental Science-Policy Platform on Biodiversity and Ecosystem Services. Retrieved from https://www.ipbes.net/news/ipbes-global-assessmentsummary-policymakers-pdf.

Doody, D.G., P.J.A. Withers, R.M. Dils, R.W. McDowell, V. Smith, Y.R. McElarney, M. Dunbar, and D. Daly. 2016. Optimising land use for the delivery of catchment ecosystem services. Frontiers in Ecology and Environment 14: 325-332. 
DeGraef, P. 2017. Food from country to city, waste from city to country: An environmental symbiosis? Fertiliser improvement in eighteenth-century Flanders. Journal for the History of Environment and Society 2: 25-61.

Dupas, R., C. Minaudo, G. Gruau, L. Ruiz, and C. Gascuel-Odoux. 2018. Multidecadal trajectory of riverine nitrogen and phosphorus dynamics in rural catchments. Water Resources Research 54: $5327-5340$.

European Commission. 2007. Eurostat pocketbooks: Agriculture main statistics 2005-2006. Luxembourg: Office for Official Publications of the European Communities.

European Environment Agency. 2015. The European Environment State and Outlook 2015. https://urldefense.proofpoint.com/v2/ urlu=https-3A_www.eea.europa.eu_soer\&d=DwIGaQ\&c= vh6FgFnduejNhPPD0fl_yRaSfZy8CWbWnIf4XJhSqx8\&r= r2aSgYn6PHMQXXmeBiK

snvfFG9T9U5fmdQ67xEVmgo0\&m=-

Ixy0WdU21fK5lWR6LQNZYltytvdmrRBgU-4QKWlbI4\&s= yhWbtt13o2O_ipPA6-Rj8SV2U4_GVJ2N0GIUauIVo1U\&e=

European Environment Agency. 2018a. European Waters: Assessment of staus and pressures. EAA Report No. 7. Publications Office of the European Union: Luxembourg.

European Environment Agency. 2018b. Nutrients in Freshwaters in Europe. Retrieved from https://www.eea.europa.eu/data-andmaps/indicators/nutrients-in-freshwater/nutrients-in-freshwaterassessment-published-6.

Folke, C., S. Carpenter, B. Walker, M. Scheffer, T. Elmqvist, L. Gunderson, and C.S. Holling. 2004. Regime shifts, resilience, and biodiversity in ecosystem management. Annual Review of Ecology Evolution and Systematics 35: 557-581.

Forber, K.J., P.J.A. Withers, M.C. Ockenden, and P.M. Haygarth. 2018. The phosphorus transfer continuum: A framework for exploring effects of climate change. Agricultural and Environmental Letters 3: 180036.

Foy, R.H. 2007. Variation in the reactive phosphorus concentrations in rivers of northwest Europe with respect to their potential to cause eutrophication. Soil Use and Management 23: 195-204.

Gordon, L.J., V. Bignet, B. Crona, P.J.G. Henriksson, T. van Holt, M. Jonell, T. Lindahl, M. Troell, et al. 2017. Rewiring food systems to enhance human health and biosphere stewardship. Environment Research Letters 12: 100201.

Helin, J., and H.-P. Weikard. 2019. A model for estimating phosphorus requirements of world food production. Agricultural Systems. https://doi.org/10.1016/j.agsy.2019.102666.

Jacobs, B., D. Cordell, J. Chin, and H. Rowe. 2017. Towards phosphorus sustainability in North America: A model for transformational change. Environmental Science \& Policy 77: 151-159.

Jarvie, H.P., A.N. Sharpley, P.J.A. Withers, J.T. Scott, B.E. Haggard, and C. Neal. 2013. Phosphorus mitigation to control river eutrophication: Murky waters, inconvenient truths and 'PostNormal' science. Journal of Environmental Quality 42: 295-304.

Jarvie, H.P., A.N. Sharpley, D. Flaten, P.J.A. Kleinman, A. Jenkins, and T. Simmons. 2015. The pivotal role of phosphorus in a resilient water-energy-food security nexus. Journal of Environmental Quality 44: 1049-1062.

Jurgilevich, A., T. Birge, J. Kentala-Lehtonen, K. Korhonen-Kurki, J. Pietikäinen, L. Saikku, and H. Schösler. 2016. Transition towards circular economy in the food system. Sustainability 8: 69.

Kleinman, P.J., A.N. Sharpley, P.J. Withers, L. Bergström, L.T. Johnson, and D.G. Doody. 2015. Implementing agricultural phosphorus science and management to combat eutrophication. Ambio 44: 297-310.
Kuemmerle, T., C. Levers, K. Erb, S. Estel, M.R. Jepsen, D. Müller, C. Plutzar, J. Stürck, et al. 2017. Hotspots of land use change in Europe. Environmental Research Letters 11: 064020.

Lathuillière, M.J., M.S. Johnson, G.L. Galford, and E.G. Couto. 2014. Environmental footprints show China and Europe's evolving resource appropriation for soybean production in Mato Grosso, Brazil. Environmental Research Letters 9: 074001.

Leinweber, P., U. Bathmann, U. Buczko, C. Douhaire, B. EichlerLöbermann, E. Frossard, F. Ekardt, H. Jarvie, et al. 2018. Handling the phosphorus paradox in agriculture and natural ecosystems: Scarcity, necessity, and burden of P. Ambio 47: $3-19$.

Lomba, A., C. Guerra, J. Alonso, J.P. Honrado, R. Jongman, and D. McCracken. 2014. Mapping and monitoring High Nature Value farmlands: Challenges in European landscapes. Journal of Environmental Management 143: 140-150.

MacDonald, G.K., E.M. Bennett, P.A. Potter, and N. Ramankutty. 2011. Agronomic phosphorus imbalances across the world's croplands. Proceedings of the National Academy of Sciences 108: 3086-3091.

MacDonald, G.K., H.P. Jarvie, P.J.A. Withers, D.G. Doody, B.L. Keeler, P.M. Haygarth, L.T. Johnson, R.W. McDowell, et al. 2016. Guiding phosphorus stewardship for multiple ecosystem services. Ecosystem Health and Sustainability 2: e01251.

McNamee, S., and K.J. Gergen. 1999. Relational responsibility: Resources for sustainable dialogue. Thousand Oaks: Sage.

Metson, G.S., D.M. Iwaniec, L.A. Baker, E.M. Bennett, D.L. Childers, D. Cordell, N.B. Grimm, J.M. Grove, et al. 2015. Urban phosphorus sustainability: Systemically incorporating social, ecological, and technological factors into phosphorus flow analysis. Environmental Science \& Policy 47: 1-11.

Morrison, T.H., W.N. Adger, K. Brown, M.C. Lemos, D. Huitema, J. Phelps, L. Evans, P. Cohen, et al. 2019. The black box of power in polycentric environmental governance. Global Environmental Change. https://doi.org/10.1016/j.gloenvcha.2019.101934.

Nawara, S., T. van Dael, R. Merckx, F. Amery, A. Elsen, W. Odeurs, et al. 2017. A comparison of soil tests for available phosphorus in long-term field experiments in Europe. European Journal of Soil Science 68: 873-885.

Neal, C., M. Bowes, H.P. Jarvie, P. Scholefield, G. Leeks, M. Neal, P. Rowland, H. Wickham, et al. 2012. Lowland river water quality: A new UK data resource for process and environmental management analysis. Hydrological Processes 26: 949-960.

Nesme, T., G.S. Metson, and E.M. Bennett. 2018. Global phosphorus flows through agricultural trade. Global Environmental Change 50: $133-141$.

Ockenden, M.C., M.J. Hollaway, K.J. Beven, A.L. Collins, R. Evans, P.D. Falloon, K.J. Forber, K.M. Hiscock, et al. 2017. Major agricultural changes required to mitigate phosphorus losses under climate change. Nature Communications 8: 161.

Powers, S.M., T.W. Bruulsema, T.P. Burt, N.I. Chan, J.J. Elser, P.M. Haygarth, N.J.K. Howden, H.P. Jarvie, et al. 2016. Long-term accumulation and transport of anthropogenic phosphorus in three river basins. Nature Geoscience 9: 353-356.

Powers, S.M., R.B. Chowdhury, G.K. MacDonald, G.S. Metson, A.H.W. Beusen, A.F. Bouwman, et al. 2019. Global opportunities to increase agricultural independence through phosphorus recycling. Earth's Future. https://doi.org/10.1029/ 2018 EF001097.

Reed, M.S. 2008. Stakeholder participation for environmental management: a literature review. Biological Conservation 141: 2417-2431.

Ruben, R., J. Verhagen, and C. Plaisier. 2019. The challenge of food systems research: What difference does it make? Sustainability 11: 171 . 
Schindler, D.W., S.R. Carpenter, S.C. Chapra, R.E. Hecky, and D.M. Orihel. 2016. Reducing phosphorus to curb lake eutrophication is a success. Environmental Science and Technology 50: 8923-8929.

Springmann, M., M. Clark, D. Mason-D'croz, K. Wiebe, B.L. Bodirsky, L. Lassaletta, W. de Vries, S.J. Vermeulen, et al. 2018. Options for keeping the food system within environmental limits. Nature 562: 519-525.

Termeer, C.J., A. Dewulf, and G.R. Biesbroek. 2017. Transformational change: Governance interventions for climate change adaptation from a continuous change perspective. Journal of Environmental Planning and Management 60: 558-576.

Torrent, J., E. Barberis, and F. Gil-Sotres. 2007. Agriculture as a source of phosphorus for eutrophication in southern Europe. Soil Use and Management 23: 25-35.

Tóth, G., A. Jones, and L. Montanarella, (Eds.). 2013. LUCAS Topsoil Survey. Methodology, Data and Results. JRC Technical Reports. Publications Office of the European Union, EUR26102 Scientific and Technical Research Series, Luxembourg.

Van Dijk, K.C., J.P. Lesschen, and O. Oenema. 2016. Phosphorus flows and balances of the European Union Member States. Science of the Total Environment 542: 1078-1093.

Withers, P.J.A., H.P. Jarvie, R.A. Hodgkinson, E.J. Palmer-Felgate, A. Bates, M. Neal, R. Howells, C.M. Withers, and H. Whickham. 2009. Characterization of phosphorus sources in rural watersheds. Journal of Environmental Quality 38: 1998-2011.

Withers, P.J.A., C. Neal, H.P. Jarvie, and D.G. Doody. 2014. Agriculture and eutrophication: Where do we go from here? Sustainability 6: 5853-5875.

Withers, P.J.A., K.C. van Dijk, T.-S.S. Neset, T. Nesme, O. Oenema, G.H. Rubæk, O.F. Schoumans, B. Smit, and S. Pellerin. 2015. Stewardship to tackle global phosphorus inefficiency: The case of Europe. Ambio 44: 193-206.

Withers, P.J.A., and M.J. Bowes. 2018. Phosphorus the Pollutant. In Phosphorus: Polluter and Resource of the Future: Removal and Recovery from Wastewater, ed. C. Schaum, 3-34. London: IWA Publishing.

Withers, P.J.A., D.G. Doody, and R. Sylvester-Bradley. 2018. Achieving sustainable phosphorus use in food systems through circularisation. Sustainability 10: 1804.

Publisher's Note Springer Nature remains neutral with regard to jurisdictional claims in published maps and institutional affiliations.

\section{AUTHOR BIOGRAPHIES}

Paul J. A. Withers $(\square)$ is a Professor of Catchment Biogeochemistry at the Lancaster University where he is investigating the cycling, processing, transfers, and impacts of phosphorus in terrestrial and aquatic ecosystems and strategies towards more sustainable management of this critical nutrient in the global food system.

Address: Lancaster Environment Centre, Lancaster University, Lancaster LA1 4YQ, UK.

e-mail: p.j.withers@lancaster.ac.uk

Kirsty G. Forber is a Research Associate at the Lancaster Environment Centre, Lancaster University. Her research interests include phosphorus cycling in catchments and developing sustainable and resilient food systems including the impacts of climate change.

Address: Lancaster Environment Centre, Lancaster University, Lancaster LA1 4YQ, UK.

e-mail: k.forber@lancaster.ac.uk
Christopher Lyon is a Research Fellow at the University of Leeds. His research interests include social adaptation and transformative responses to contemporary environmental challenges.

Address: Sustainability Research Institute, University of Leeds, Leeds LS2 9TJ, UK.

e-mail: c.lyon@leeds.ac.uk

Shane Rothwell is a Senior Research Associate at the Lancaster University. His research interests include phosphorus-use efficiency in agriculture, alternative phosphorus resources and crop physiological responses to phosphorus deficiency and soil $\mathrm{pH}$ management. Address: Lancaster Environment Centre, Lancaster University, Lancaster LA1 4YQ, UK.

e-mail: s.rothwell1@lancaster.ac.uk

Donnacha G. Doody is Programme Leader for Catchment Science in the Agri-Food and Bioscience Institute of Northern Ireland. His research interests include the impact of land use on aquatic ecosystems, with a particular focus on phosphorus.

Address: Agri-Food and Bioscience Institute, Belfast BT9 5BX, UK. e-mail: donnacha.doody@afbini.gov.uk

Helen P. Jarvie is a Principal Research Scientist in Hydrochemistry at the Centre for Ecology and Hydrology, Wallingford, U.K. Her research interests include river-system biogeochemistry, with particular emphasis on nutrient (phosphorus and nitrogen) cycling, water quality and eutrophication, from watershed to global perspectives. Address: Centre for Ecology and Hydrology, Wallingford, Oxfordshire OX10 8BB, UK.

e-mail: hpj@ceh.ac.uk

Julia Martin-Ortega is a Professor of Ecological Economics at the Sustainability Research Institute, University of Leeds. Her research furthers the understanding of the relationships of society and individuals with water systems and how policy can best make use of this understanding to promote the sustainable management of water and land resources.

Address: Sustainability Research Institute, University of Leeds, Leeds LS2 9TJ, UK.

e-mail: j.martinortega@leeds.ac.uk

Brent Jacobs is an Associate Professor and Research Director in the University of Technology Sydney's Institute for Sustainable Futures. His current research interests include transformation, vulnerability, and adaptive capacity of communities to support climate change adaptation. He leads the Adaptive Communities Node of the New South Wales Climate Adaptation Research Hub.

Address: Institute for Sustainable Futures, University of Technology, Sydney, Australia.

e-mail: brent.jacobs@uts.edu.au

Dana Cordell is a Research Director in the Institute for Sustainable Futures at the University of Technology Sydney where she leads the Food Systems group. She is a global phosphorus vulnerability and security expert whose current research focuses on urban food systems in Australia, U.S., Vietnam and Malawi and on how they can transform in response to the emerging global $\mathrm{P}$ challenge.

Address: Institute for Sustainable Futures, University of Technology, Sydney, Australia.

e-mail: dana.cordell@uts.edu.au 
Myles Patton is an Agricultural Economist at the Agri-Food and Biosciences Institute of Northern Ireland. His research interests include agricultural commodity markets and land use change.

Address: Agri-Food and Bioscience Institute, Belfast BT9 5BX, UK. e-mail: myles.patton@afbini.gov.uk

Miller A. Camargo-Valero is an Associate Professor of BioResource Systems at the University of Leeds. His research interests include the recovery of resources from waste streams by optimising the anthropogenic carbon, nitrogen, phosphorus and water cycles.
Address: BioResource Systems Research Group, School of Civil Engineering, University of Leeds, Leeds LS2 9JT, UK.

e-mail: m.a.camargo-valero@leeds.ac.uk

Rachel Cassidy is a Senior Scientist at the Agri-Food and Biosciences Institute (AFBI). Her research interests include water-quality monitoring, farm-to-catchment scale nutrient management and hydrological modelling.

Address: Agri-Food and Bioscience Institute, Belfast BT9 5BX, UK. e-mail: rachel.cassidy@afbini.gov.uk 